\title{
Quarantined histories: Sindh and the question of historiography in colonial India- Part I
}

\section{Manan Ahmed Asif (ib}

Columbia University, New York, USA

\section{Correspondence}

Manan Ahmed Asif, 1180 Amsterdam Avenue, Fayerweather Hall 502, New York, NY 10027, USA.

Email: ma3179@columbia.edu

\begin{abstract}
This essay examines histories of colonial British India and the annexation of Sindh in 1843 from two perspectives. The first is the colonial historiographic project that frames the history of Islam in India, creates an archive for its study and produces the political and military dominance of Sindh. Fundamentally, it argues that Muslims in India cannot produce their own histories for they lack the language and archives for scientific objectivity. In response, a set of Indian intellectuals take on the project of writing histories of Sindh from 1890 to 1950 s. These histories are written in direct dialogue with the colonial archive and insist on their engagement with social scientific methodologies and tools. In rethinking this past, the essay argues that that Urdu historiography was itself deemed unscientific by modern South Asian historians and abandoned as not "proper history." This essay thus asks that we incorporate such histories in our genealogies of anticolonial past.
\end{abstract}

\section{1 | INTRODUCTION}

This essay concerns the matter of writing medieval history. I am interested in a set of vernacular texts, titled either Tari'kh-i Hind (History of India) or Tari'kh-i Sindh ("History of Sindh"), written between 1890 and 1950 by a diverse set of Indian Muslim intellectuals. These texts, taken as an archive, form a sustained engagement with the wider concerns of history writing and the specific concern of writing the history of a political and geographic space in British India-Sindh: a princely state from the mid eighteenth century onwards, with two major ports, Thatta and Karachi. There are some unique characteristics of these histories that mark them as worthy subjects of inquiry. They focus on a particular political space and its deep past and allow us to think about the politics of longue durée history in India. They explicitly engage with colonial historiographic frameworks and with the colonial dismissal of historical consciousness among Indians. They foreground their deployment of social scientific forms of historical knowledge production-footnotes, source-criticism, archival research, and bibliographies. They emerge alongside yet outside of academic disciplinary production of history in British colonial India.

A history of history writing on Sindh has not received attention from the modern historian. ${ }^{1}$ This is surprising because, as I will demonstrate, Sindh was the political borderlands that sparked both the emergence of the greatest archival and translation project of the British colonial regime and also its archaeological and popular historical one. Though there exist histories of political rule in Sindh, they are not concerned primarily with the politics of the 
writing of history itself (Cook, 2015). In focusing on Sindh, my effort is not to reproduce another history of a particular region but to enunciate the importance of Sindh as a political space par excellence for late colonial India? ${ }^{2}$ Similarly, when thinking about the positivist histories of Sindh written in the late nineteenth and early twentieth century, I do not wish to recuperate them but to contextualize them. To put it differently, this is a history of the historical imagination about Sindh-one that brings into relief the arguments binding colonial historiography and vernacular historiography.

Sindh demonstrates an intimate relationship between geography and history on very unique terms. Sindh was understood by the colonial historian to be the first region conquered by Muslims in $712 \mathrm{CE}$ and hence the geography under longest Muslim political rule in northern India. This entrenched understanding of Muslim history and Indian geography propelled the East India Company to conquer Sindh in 1843. A history of Sindh was a genealogical project for the colonial state: It historicized the "Oriental despot" long popularized by the likes of Alexander Dow, James Mill, and Karl Marx. Sindh was the ur-space where Muslim belonging in India could be directly contested. Here, the colonial historian could demonstrate as a historic, scientific "fact" that Islam was foreign and Muslim were conquerors to India. Company officials, political agents, and chroniclers produced histories of Sindh since the early nineteenth century, and these synthetic narratives created the discursive grounds for Sindh as a political space. Resisting it is a historiographic thread of writing histories of Sindh and India in Urdu that runs throughout the late nineteenth century and to the 1947 independence. That is the thread that interests me, and from it, I want to weave an understanding of the emergence of social scientific genre conventions in Urdu and the relationship of this archive to the broader field of intellectual history in India.

The essay is divided into two parts and four sections. In the first part, I begin with revisiting the colonial construction of an archive for studying Muslim pasts in India. Next, I turn towards the political history of Sindh and the ways in which its political geography framed its historiographic inquiry. Having laid out the colonial terrain, the second part examines vernacular histories of Sindh focusing on the prefatory remarks on the task of history writing by the Muslim intellectuals, their employment of "facts," archival visits, footnotes, source-criticism, and bibliography as markers of their historical consciousness. In the concluding section, I reflect on their marginalized status and why they have been quarantined within the field of South Asian history.

\section{I CONSTRUCTING AN ARCHIVE FOR MUSLIM HISTORY}

The wide contours of the British colonial knowledge production in India are well known but bear repetition here (Bayly, 1996; Cohn, 1996; Metcalf, 1994). In India, from the mid eighteenth century onwards, the British colonial regime, at varied places and with varied results, created a knowledge economy within which India's peoples, histories, and land were surveilled, archived, summarized, and operationalized. This large scale effort included thousands of young men from Scotland, Ireland, and England, who sat exams and were posted by the East India Company to Bengal, Bombay, Madras, and Uttar Pradesh where they served in tenures as long as 20 years. On the other hand, employed into the Company and later the Raj were hundreds of thousands of Indian letterists, secretaries, lawyers, cartographers, reporters, and clerks, who helped amassed the largest collection of territorial, linguistic, and cartographic data until the Soviet State post-World War II.

This vast trove of data was never dormant. It lived alongside and within a hegemonic archive of news reports, gazetteers, laws, travelogues, histories, novels, memoirs, museums, and material culture that we now understand as the legacy of colonial rule in India. The making of this archive was not just in imperial, military, legal, or medical branches of the East India Company but also in research societies and colleges-Calcutta's The Asiatick Society was founded in 1784 and Fort William College in 1800. While the College had "native" language instructors from the beginning, the, now renamed, Asiatic Society admitted Indian scholars only after 1829. A key output of both the Society and the College were grammars, phrase-books, translations, and critical editions of Sanskrit, Persian, and other Indic language texts. Indian scholars, scribes, and researchers were involved in the making of these foundational bricks 
of the imperial edifice-though their efforts and intellectual labors were largely written out of existence. ${ }^{3}$ What is important for our discussion here is that social scientific forms of knowledge were coproduced and coconstructed in the early nineteenth century.

Leaving in suspension the issue of the forgotten labor, and intellectual capacity, of Indian scholars in producing colonial knowledge, I want to highlight the question of their historical consciousness under the colonial episteme. G.W.F. Hegel's 1822-1823 "Lectures on the Philosophy of World History" (Vorlesungen über die Philosophie der Weltgeschichte) provides one broad assessment when he characterized India as "a land of fantasy (Phantasie)" where there is "no thought of history, of chronology or the presentation of actuality" (Hegel, 2011, p. 252-253). As people, Hegel averred, the Indians were caught in a dream life (of opiates and luxury) such that the "universal" as a concept was wholly absent. Their lack of subjective or objective insights-the inability to see outside of the "worrisome drama" of a "ceaseless interplay of uprisings, conspiracies, and brutal episodes"-meant that they had "no authentic history" (Hegel, 2011, p. 287). Lacking individual subjecthood and universal categories of analysis, the Indians were unable to produce their own history, and thus, the Indian subject looked to "foreigners"-the Greek, the Muslim, and then the English.

Hegel's assessment rested largely on the translations of key Sanskrit texts (Laws of Manu, portions from Mahabharata) by William James, the translation of Firishtā's Tar'ikh (History) from 1610 CE by Alexander Dow in 1768, and the synthetic work of John Mill in his 1817 History of British India. Here is demonstrated the unique circularity in British colonial knowledge systems-the production of raw data to the construction of a category of knowledge, back to the production of raw data to fill that category with meaning, so on and so forth. The translations and histories revealed to Hegel the very philosophical category for India, which in turn informed the creation of new Indian archives for preservation and consumption by the European scholar.

A demonstrative example is Aloys Sprenger (1813-1893), the principal of Mohammadan College in Delhi, who is asked to create a catalogue of manuscripts held in princely courts across north India in 1841-a charge that he turned into a massive collecting project stretched across the Muslim world. Sprenger saw "admittedly little intrinsic value" in these manuscripts he was acquiring for "they contains few facts, if any, in astronomy, medicine, mathematics, natural history, or any other science, which are new to us" (Sprenger, 1854, p. v). Yet he argued that they had to be collected for the Muslims themselves are "apathetic" and "imbecile" and have exhausted any desire to build any archives. Hence, the European, for whom the study of the East is a "most important desideratum," will need to build his own. Sprenger was asked to undertake this archivization project by Henry Miers Elliot (1808-1853), an East India Company official in the Revenue Department (and later Foreign Department) in Punjab and Northwest Provinces (now Uttar Pradesh). Elliot began his own efforts with a project to produce a bibliography of Muslim manuscriptsfor which he commandeered Sprenger. However, he quickly pivoted to acquiring the manuscripts themselves and building a teleological archive of Muslim past in India. The Muslim conquest of Sindh in 712 CE was Elliot's understanding of their origins-that is where he turned. Like Sprenger, Elliot contracted Company political agents in Sindh to acquire, list, and translate histories of Sindh. He also amassed a coterie of Indian translators and compilers who were tasked with the extracting selections from texts deemed historical primary sources for telling the history of "Mohammadan Rule" in India. Published posthumously by John Dowson, from 1867-1877, the The History of India as Told by Its Own Historians contained excerpts from some 261 Arabic and Persian histories-beginning with the history of Arabs in Sindh.

Elliot, and later John Dowson, selected and prepared both translations and analytical gloss for this vast archive, with the aim that "the full light of European truth and discernment begins to shed its beams upon the obscurity of the past, and to relieve us from the necessity of appealing to the Native Chroniclers of the time, who are, for the most part dull, prejudiced, ignorant and superficial" (Elliot \& Dowson, 1867, p. xx). Elliot, in his capacity as compiler and translator, had little respect for either the past Muslim Chroniclers or indeed their present avatars. In his preface, he notes that the "Native Chroniclers"-that is Elliot's contemporaries-were prone to such exaggerations and had such little regard for scientific truth that they often invented titles, entire works, or plagiarized material from known sources and claimed them as their own. ${ }^{4}$ 
Elliot's dismissal of Indian historians was the colonial embrace of the Hegelian view of Indian history-because the Indians had no philosophy of history, hence, they had no history. The virtue, for Elliot, in his archival aggregation laid in the fact that the texts collectively demonstrated the "successive conspiracies, revolts, intrigues, murders and fratricides" perpetrated by the Muhammad Kings of old and hence exposed the Muslim "kings, even of our creation, sink in sloth and debauchery, and emulating the vices of a Caligula or a Commodus." Exposing such historical truths, Elliot hoped would "make our native subjects more sensible of the immense advantages accruing to them under the mildness and equity of our rule" (Elliot \& Dowson, 1867, p. xx). The first layer of this archive for the study of Oriental despotism was the history of the region of Sindh.

The groundwork done-the manuscripts collected by Sprenger and Elliot ended up in Berlin and London-The History of India became the active and the passive archive for a range of far reaching and influential colonial histories: passive in the sense that the secondary scholarship following Elliot in later nineteenth and early twentieth century drew upon the edited Persian texts and their translations and active in the sense that new translations and critical editions of manuscripts "discovered" by Elliot and Sprenger were produced by the new generation of Orientalists. Three of the most influential histories produced after Elliot were William Wilson Hunter's A History of British India (1899), Stanley Lane-Poole's Medieval India under Muhammadan Rule, 712-1764 (1903), and Vincent A. Smith's The Oxford Student's History of India (1908).

Hunter, as the Director General of Statistics to the Government of India, had coordinated and published, between 1875 and 1877, the 20-volume The Statistical Account of Bengal, which amassed the full project of mapping, surveilling, and knowing the colonized landscape and bodies. This project was then extended to the 128-volume The Statistical Survey of India. Hunter's project employed and trained a vast army of native cartographers and reporters, who walked India to gather and report back data concerning its people. If Elliot's project was to gather the raw materials for history, Hunter's was to give it the scientific standing and to produce the synthetic survey.

In writing a history based on the data collected under his office, Hunter expressly meant for his A History of British India to supplant Gibbon's "Decline and Fall of the Roman Empire." He marshalled the data from the census, the map, and the texts provided by Elliot: "I have done a good piece of work in the History, and I know it. So let the world wag. Whatever the reviewers may say or not say about it now, those who really wish to learn the facts about India will find them there and there alone" (Skrine, 1901, p. 470). Where Elliot had created the archive, Hunter created the "fact." Lane-Poole and Smith, in turn, produced the analytical voice-introducing social scientific footnotes, bibliographies, source-criticism, and utilization of these facts to create a seamless narrative of history, to be used for the training of both native and English students of the Raj (Inden, 1986, p. 401-446). They turned facts into narrative truth.

Where Elliot's translation project fractured Persian histories into chunks suitable for historical inquiry into one sectarian past alone, the "connected" history projects of Smith and Lane-Poole reknit them into an overwhelmingly powerful narrative. The Muslims, pegged as outsiders and conquerors in the Indian past, were the fanatic outsiders of the British colonial present as well. Sindh was the space where the particular cruelty of Muslim rule was at its most transparent. All three of them took their cue from Elliot and either marked Sindh as the political space of special notice or began their history-as Lane-Poole-with the year 712 and the Muslim arrival in Sindh. After the conquest of Sindh in 1843, it was also the site where British efforts to rehabilitate India could be cast in the starkest terms.

Let us turn now to the Orientalist histories of Sindh and their political impact.

\section{3 | THE HISTORY OF GEOGRAPHY}

The British conquest of Sindh was not simply a political act. It was also a historiographic act based on an epistemology that asserted the "foreign-ness" of Muslims and an ur-space for their arrival to India. As a project, it was based on the efforts of archivization and translation by a group of Company officials who were philologists, archeologists, and historians. The Company's own conquest of Sind was cast as a corrective to the Muslim conquest-a move to proclaim 
the emancipation of Hindus from the clutches of the foreign Muslims. It is important now to trace that historiographic project now that its culmination-the conquest of Sindh-is clearly in view.

It is here that we must move beyond known general genealogies of colonial knowledge towards the lesser-known histories of particular geographies in British India-specifically borderlands. Sindh-centered around the delta of the Indus opening into the Arabian Gulf-was a region composed of a series of ports and large swaths of dry, desert-like terrain. Gujarat, Rajastan, Punjab, and Baluchistan surround it on contemporary maps, but at the beginning of the nineteenth century, it emerged as an important borderlands space for the East India Company. Indus, the as-yet, uncharted by the Company, river provided an upstream link from Bombay to Lahore, the capital of Ranjit Singh's Sikh imperium. Across the Thar and Baluchi desert, Sindh linked to the Durrani court in Kabul. The East India Company had long established its Bombay Presidency when it began to think about Sindh as a necessary buffer against Afghanistan (as well the French and Russian) interests.

Hence, in 1800, Nathan Crow was sent as an emissary from Bombay to the court of the rulers of Sindh-the Talpur Mirs-to sign the first treaty between the East India Company and the Princely State. The Talpur, wary of foreign troops on their land, signed the treaty to keep the Company at bay for a while. In 1809, another treaty was negotiated to "prevent any establishment of the tribe of French in Sind" and again, in 1820, to further restrict the settlement of any "Europeans or Americans" in the region (Aitchison, 1892, p. 308-309). These sets of treaties established Sindh as a political space-a borderlands region that allowed the Company bulwark against its imagined enemies.

Intimately connected to the military utility of political space was its commercial utility. The Company's desire to chart the waters of the Indus brought Alexander Burnes (1805-1841) to the port of Karachi in 1830. His ostensible mission was to deliver presents from the king of England to Ranjit Singh. Burnes notes that as he ascended the river, a local elite ("Syud") turned to his companion and said, "Sinde is now gone, since the English have seen the river, which is the road to its conquest." Hearing that, Burnes commented, "If such an event do happen, I am certain that the body of people will hail the happy day; but it will be an evil one for the Syuds, the descendants of Mahomed, who are the only people, besides the rulers that derive precedence and profit from the existing order of things" (Burnes, 1835, 36). Note here the marking of Sindh's political rule as particularly despotic and the ostensible claim to provide emancipation to the "body of people." Burnes's voyage did end up opening the channels of the Indus to the Company. It could now control the traffic over the Indus of opium coming from Malwa to the Portuguese harbors of Daman and Diu in Gujarat, by way of the Karachi harbor. In 1839, they captured that port of Karachi.

The British defeat in the first Anglo-Afghan war, prompted Edward Law Ellenborough, the Governor General of the Company, to order the annexation of Sindh. He chose Charles Napier, a veteran military commander of imperial wars in Europe and self-described victim of fool-hardy politicians, for the task. Napier had only recently arrived in India and was convinced that the Company had lost its moorings in India and became beholden to commerce and shying away from their Godly mission. A deeply religious man, Napier, saw the liberation of Sind from its despotic Muslim rulers as his Christian duty. He believed that the Talpur were the "greatest ruffians," "imbeciles," possessing "zenanas filled with young girls torn from their friends, and treated when in the hareem with revolting barbarity," and even prone to enjoying the occasional "human sacrifice" (Napier, 1845, p. 327-369). On 17 February 1843, Napier defeated the assembled troops of the Talpur at Miani and annexed Sind to the Company. Initially, the conquest was hailed as a heroic return of an East India Company long oundering in bureaucratic miasma. Some even claimed that "since Clive's glorious victory at Plassey there has been nothing achieved by native or European troops in India at all to compare to it" (Postans, 1843, p. 334).

Captain James McMurdo, who traveled up the Indus River in 1812, was instrumental in excerpting and translating early Sindhi history. His account of the journey brought to Elliot's attention the thirteenth century Persian history Chachnama and the seventeenth century text Tufatul Kiram. McMurdo believed that Muslims rulers in Sindh were "the most bigoted, the most self-sufficient and the most ignorant people on record" (McMurdo, 1834, p. 244). In Sindh, the Hindu "has for many centuries know no other government but that of Islam" such that "in the course of 
a thousand years there is not an instance of a Hindu having attempted to rescue himself or fellow-countrymen from a state of vilest slavery" (McMurdo, 1834, p. 251).

Although McMurdo died of cholera, his posthumous papers were published in 1834 alongside the work of another young political agent, Thomas Postans, who published important translations from Persian histories of Sindh in the Journal of the Royal Asiatic Society of Bengal in 1838. Postans was not the only subordinate of Charles Napier traveling across Sind. The hills of Thatta were also the training grounds for the Orientalist translators and explorers, Richard F. Burton and Edward Eastwick-all contributed to the historiographic exercise by translating excerpts from Persian histories of Sindh and writing broad accounts of their sojourn in the region.

Postans, in 1838, wrote about the impact of the Muslim arrival in 712 CE as follows:

Sind ... under its Hindu possessors was a rich, flourishing, and extensive monarchy, but that, subsequently becoming the prey of conquerors, who, paid no attention to the improvement of the country or maintenance of the imperial authority, this valuable territory dwindled at length into waste .... All the peculiarities and unsullied pride of caste, which distinguishes the Hindu under his own or British government, has been completely lost in Sind. In India we have seen the dormant spirit of an injured people rousing itself to retributive vengeance, flinging off the yoke of Islam, regaining their monarchies, and making the bigoted Moslem tremble at the Pagan's power; but in Sind oppression has rooted out all patriotism, and the broken spirited Hindu becomes a helpless servant to his Moslem tyrant, and willing inducer of his own extreme degradation (Postans, 1843, p. 158-160).

Richard F. Burton produced three monographs on his time in Sindh-Scinde, or the Unhappy Valley (1851), Scinde, and the Races that Inhabit the Valley of the Indus (1851), and Falconry in the Valley of Indus (1853)-in which he used Persian histories and his ethnographic observations to conclude much the same as Postans: "It is related by the chronicles of antiquity, that in days gone by, and ages that have long fled, Scinde was a most lovely land situated in a delightful climate, with large, flourishing, and populous cities; orchards producing every kind of tree and fruit... it was resolved, with the permission of Allah, to subject the sinners of Scinde to the scimitar of certain sturdy saints militant" (Burton, 1851, p. 125). Burton posited a paradise of ancient Sindh, destroyed by the fanaticism of the marauding Muslims, resulting in the arrival of the long dark ages. The region waited even longer than Bengal, for instance, for its emancipation. Burton's rewriting of Muslim history went further, emphasizing in tremendous detail the ancient wartime atrocities allegedly committed by Muslims against Hindus.

Elliot died before the publication of his vast translation project. However, he did publish one book while he was ailing in Cape Town in 1853: "Appendix to the Arabs in Sind, Vol. III, part 1 of the Historians of India." The book contains Elliot's own essay on the arrival of Arab conquerors in the eighth century and his gloss on Indian character via a study of their war techniques. Why did Elliot write on Sindh? There can be no doubt that there is an explicit and immediate link between these narratives of Sindh's past in Postans and Burton, and Charles Napier's casting of himself as the liberator of Sindhi people. Napier repeatedly used the argument of Muslim brutality in the pasts of Sindh to paint the current Talpurs as usurpers, with "their stupid policy to injure agriculture, to check commerce, to oppress the working man, and to accumulate riches for their own sensual pleasures" (Napier, 1845, p. 37). Elliot used both the archival discoveries of McMurdo and Postans as well the ethnographic certainties of Burton in compiling his archive and creating his understanding of Islam's origins in India. Elliot's hope was that "the inhabitants of modern India, as well as our clamorous demagogues at home," remember "the very depth of degradation from which the great mass of the people have been raised, under the protection of British supremacy" (Elliot \& Dowson, 1867, p. 479).

The latter half of the nineteenth century saw a vast production of archival, historiographic, and archaeological knowledge about the historical geography of Sindh by the colonial regime. The first Commissioner of Sindh, Bartle Frere, contributed "Memorandum on some Buddhist Excavations near Karādh" to the Journal of the Bombay Branch of the Royal Asiatic Society in 1851. In 1853, A. F. Bellasis, a civil servant in Bombay, published in the same journal "An Account of the Ancient and Ruined City of Brahminabad, in Sind." In 1862, the Archaeological Survey of India was formed under Colonel Alexander Cunningham. Cunningham noted that alongside the Trignometrical Survey, 
the Archaeological Survey would credit both the "enlightened ruling power" and the "claims of science" (Cunningham, 1871, p. ii-iii). Sindh as site of Buddhist past in India would be part of this investigation. From 1891 to 1893 , Henry Cousens led the archaeological survey of India on "the northern frontiers of Sind to the River Savitri." In his report, Cousens wrote that "Of Hindu remains in Sind, little is to be found, owing to the havoc wrought by the Arab conquerors. That such buildings did exist is plain from the great temple at Deval [Daybul], which they destroyed, and the fragments built into the tomb of Nindo at Thatha" (Cousens, 1975, p. 9). The discovery of the ancient ruins of Harappa by D. R. Sahni in 1921 and the excavations at Mohenjo-daro in Sind in 1925-1926, under John Marshall, meant that Sind was firmly situated as an ur-space for India.

This extensive engagement with the Company's military, historical, and archaeological projects demonstrates the contours of inquiry into Muslim past in India. For the colonial historian, any enquiry concerning historical knowledge about origins of Muslim rule in India, about the foundation of that rule, and about the evil consequences of that rule would necessarily be an enquiry into the history of Sindh. McMurdo, Postans, Burton, and Elliot deployed comparative philology, material archaeology, ethnography, and other claims to scientific knowledge for laying bare the "truth" of the history of Sindh. When Muslim intellectuals in late nineteenth century reacted against the hegemony of this knowledge, they have no choice but to write the history of Sindh and that necessitated their own deployment of the very same grounds of philology, history, and archaeology.

Writing from the 1870s onwards, the erstwhile subjects of history-the Muslim intellectuals and the history of "their" India-faced unique challenges in engaging with the domain of history writing. In the second part of this essay, I will turn to the response in vernacular histories to this colonial knowledge project and detail the ways in which Muslim historians engaged with Elliot and company on the domain of history writing.

\section{ENDNOTES}

${ }^{1}$ Contemporary scholarship has tackled the subject of Indians writing history of regions in various guises-in nationalist histories in Bengal and Maharashtra (e.g., Partha Chatterjee, Dipesh Chakrabarty, Prachi Deshpande, Gyan Prakash) or in discussions of development of academic institutes in particular regions (e.g., David Lelyveld, Kavita Datla).

2 I use "political space" to incorporate spatial understandings of politics as an analytical category against the more traditionally used "region." Sindh is a geographic region, but it is specifically imagined as a political space by the colonial regime, as I will discuss below.

3 See the discussion of Orientalism's "genesis amnesia" in Tavakoli-Targhi, Refashioning Iran, 18-31.

4 "A native gentleman furnished a catalogue of the manuscripts said to compose the historical collection of his Highness the Nizām; but on close examination I found that, from beginning to end, it was a complete fabrication." See Elliot, The History of India, as Told by Its Own Historians: The Muhammadan Period, vol 1, xvii.

\section{BIBLIOGRAPHY}

Aitchison, C. U. (1892). A collection of treaties, engagements, and Sanads relating to India and neighboring countries (Vol. 7). Calcutta: Office of the Superintendent of Government Printing.

Bayly, C. A. (1996). Empire and information: Intelligence gathering and social communication in India, 1780-1870. Cambridge: Cambridge University Press.

Burnes, A. (1835). Travels into Bokhara: Being the account of a journey from India to Cabool, Tartary and Persia. Also, narrative of a voyage on the Indus, from the sea to Lahore. Philadelphia: E. L. Carey and A. Hart.

Burton, R. F. (1851). Scinde; or, the unhappy valley. London: R. Bentley.

Chakrabarty, D. (2015). The calling of history: Sir Jadunath Sarkar and his empire of truth. Chicago: University of Chicago Press.

Chatterjee, P. (1993). The nation and its fragments: Colonial and postcolonial histories. Princeton, NJ: Princeton University Press.

Cohn, B. S. (1996). Colonialism and its forms of knowledge: The British in India. Princeton, NJ: Princeton University Press.

Cook, M. A. (2015). Annexation and the unhappy valley: The historical anthropology of Sindh's colonization. Leiden: Brill.

Cousens, H. (1975). The antiquities of Sind. Karachi: Oxford University Press.

Cunningham, A. (1871). Archaeological survey of India, 1. Simla: Government Central Press.

Datla, K. (2013). The language of secular Islam: Urdu nationalism and colonial India. Honolulu: University of Hawai'i Press. 
Deshpande, P. (2007). Creative pasts: Historical memory and identity in Western India, 1700-1960. New York: Columbia University Press.

Elliot, H. M., \& Dowson, J. (1867). The history of India, as told by its own historians: The Muhammadan Period. London: Trübner and Co.

Hegel, G. W. F. (2011). Lectures on the philosophy of World History. Oxford: Oxford University Press.

Inden, R. B. (1986). Orientalist constructions of India. Modern Asian Studies, 20, 401-446.

Lelyveld, D. (1978). Aligarh's first generation: Muslim solidarity in British India. Princeton, NJ: Princeton University Press.

McMurdo, J. (1834). An account of the country of Sindh; with remarks on the state of society, the government, manners, and customs of the people. Journal of the Royal Asiatic Society of Great Britain and Ireland, 1, 233-258.

Metcalf, T. R. (1994). Ideologies of the Raj. Cambridge: Cambridge University Press.

Mill, J. (1820). The history of British India (Vol. 1). London: Baldwin, Craddock and Joy.

Napier, W. F. (1845). The conquest of Scinde. London: T. \& W. Boone.

Postans, T. (1843). Personal observations on Sindh; the manners and customs of its inhabitants; and its productive capabilities: With a sketch of its his- tory, a narrative of recent events, and an account of the connection of the British government with that country to the present period. London: Longman, Brown, Green and Longmans.

Prakash, G. (1999). Another reason: Science and the imagination of modern India. Princeton, NJ: Princeton University Press.

Skrine, W. (1901). Life of Sir William Wilson Hunter. London: Longmans, Green.

Sprenger, A. (1854). Catalogue of the Arabic, Persian and Hindus'tan'y manuscripts of the libraries of the king of Oudh. Calcutta: Baptist Mission Press.

Tavakoli-Targhi, M. (2001). Refashioning Iran: Orientalism, occidentalism, and historiography. New York: Palgrave.

Manan Ahmed Asif is an Assistant Professor in the Department of History at Columbia University.

How to cite this article: Asif MA. Quarantined histories: Sindh and the question of historiography in colonial India- Part I. History Compass. 2017;15:e12403. https://doi.org/10.1111/hic3.12403 